\title{
ARENA OLAHRAGA KECEPATAN DAN AKSELERASI DI JAKARTA
}

\author{
Olivia $^{1)}$, Sutrisnowati Machdijar ${ }^{2)}$ \\ 1) Program Studi S1 Arsitektur, Fakultas Teknik, Universitas Tarumanagara, olivia.tjahyadi@yahoo.com \\ 2) Program Studi S1 Arsitektur, Fakultas Teknik, Universitas Tarumanagara, sutrisnowatim@ft.untar.ac.id
}

\begin{abstract}
Abstrak
DKI Jakarta sebagai kota metropolis memiliki kepadatan penduduk yang besar, aktivitas yang tinggi, dan pergerakan yang kuat. Kehidupan di kota besar seperti DKI Jakarta yang penuh dengan aktivitas dan rutinitas dapat menimbulkan kejenuhan dan tekanan mental pada masyarakatnya. Hal ini juga menyebabkan keterbatasan waktu luang mereka untuk bersantai guna melepas kejenuhan akan rutinitas yang dijalankan setiap harinya. Dalam kondisi seperti inilah dibutuhkan suatu prasarana untuk mendapatkan perubahan suasana dan menjadi suatu rekreasi yang dapat memulihkan dan menyegarkan kembali jiwa dan raga. Kegiatan masyarakat dalam hal melakukan olahraga rekreasi saat ini masih sangatlah kurang. Selain faktor kesadaran akan pentingnya olahraga yang berasal dari dalam diri sendiri, faktor lain yang menghambat masyarakat untuk melakukan olahraga rekreasi adalah mengenai sarana dan prasarana yang tersedia untuk mendukung kegiatan tersebut. Kawasan Wijayakusuma merupakan sebuah kawasan di Jakarta Barat yang memiliki kepadatan penduduk yang tinggi tetapi tidak banyak memiliki ruang publik dan sarana olahraga untuk berekreasi, kawasan ini memiliki site yang sangat strategis untuk dibangunnya sebuah sarana olahraga rekreasi yang juga akan berperan sebagai sebuah ruang penyambung dalam kawasan tersebut. Sarana olahraga yang akan dibuat akan memfasilitasi olahraga rekreasi yaitu olahraga bowling, sepatu roda dan go-kart indoor, serta akan menambahkan fungsi lain yaitu sebagai penyatu kawasan yang bersifat bangunan sebagai sirkulasi publik dan ruang terbuka.
\end{abstract}

Kata kunci: Boling, Go-kart, Olahraga rekreasi, Sepatu Roda, Wijayakusuma

\begin{abstract}
DKI Jakarta as a metropolis city has a large population density, high activity, and strong economic flow. Living in a big city like DKI Jakarta which is full of activities and routines can lead to boredom and mental health issue on the society. This also causes the limitation of their free time to relax in order to release boredom of the routine that is carried out every day. In this case, an infrastructure is needed to get a change of atmosphere and become a recreation place that can restore and refresh the body and soul. Community activities in terms of carrying out recreational sports are currently very lacking. In addition to the factor of awareness of the importance of sports originating within oneself, other factors that prevent the community from doing recreational sports are regarding the facilities and infrastructure available to support these activities. Wijayakusuma is an area in West Jakarta that has a high population density but does not have much public space and sports facilities for recreation purpose, this area has a very strategic site for the construction of a recreational sports facility which will also serve as a connecting space in the area. Sports facilities that will be created will facilitate recreational sports which is bowling, roller skates and indoor go-karts, and will add other functions, will be as a associate of the area as public and open space circulation.
\end{abstract}

Keywords: Bowling, Go-kart, Recreational Sport, Roller Skating, Wijayakusuma

\section{PENDAHULUAN}

DKI Jakarta merupakan sebuah kota metropolis karena merupakan "induk" bagi kota-kota sekitarnya. DKI Jakarta memiliki kepadatan penduduk yang besar, aktivitas yang tinggi, dan 
pergerakan yang kuat. Hal ini juga menyebabkan keterbatasan waktu luang mereka untuk bersantai guna melepas kejenuhan akan rutinitas yang dijalankan setiap harinya. Dalam kondisi seperti inilah dibutuhkan suatu sarana untuk mendapatkan perubahan suasana dan menjadi suatu rekreasi yang dapat memulihkan dan menyegarkan kembali jiwa dan raga. Di sisi lain kegiatan masyarakat dalam hal melakukan olahraga rekreasi saat ini masih sangat kurang. Selain faktor kesadaran akan pentingnya olahraga yang berasal dari dalam diri sendiri, faktor lain yang menghambat masyarakat untuk melakukan olahraga rekreasi adalah mengenai sarana dan prasarana yang tersedia untuk mendukung kegiatan tersebut. Kawasan Wijayakusuma merupakan salah satu sebuah area di Jakarta Barat yang memiliki kepadatan penduduk yang tinggi tetapi tidak banyak memiliki ruang publik dan sarana olahraga untuk berekreasi, oleh karena itu dengan potensinya perlu adanya sebuah prasarana olahraga rekreasi sehingga bisa menjadi wisata bagi masyarakat kawasan Wijayakusuma.

Tujuan dari perencanaan proyek ini adalah:

- Untuk merancang sebuah produk pariwisata yang bisa menghadirkan program dan bentukan arsitektural yang menarik wisatawan.

- Untuk menentukan jenis pariwisata olahraga dan kesehatan yang cocok untuk sebuah kota metropolis.

- Untuk mengetahui pengaruh produk pariwisata tersebut terhadap lingkungan sekitarnya.

\section{METODE}

Metode pengumpulan data yang digunakan sebagai berikut :

a. Survey Lapangan

Survey dilakukan di Kawasan Wijayakusuma, Grogol, Jakarta Barat. Hasil yang didapatkan sebagai berikut:

- Situasi dan kondisi Kawasan Wijayakusuma, aktivitas masyarakat, hubungan antar zonasi.

- Jenis kegiatan olahraga yang sering dilakukan masyarakat di Kawasan Wijayakusuma.

- Fasilitas di sekitar tapak di kawasan Wijayakusuma.

- Sirkulasi Kawasan Wijayakusuma.

b. Survey Online

Survey online dilakukan kepada 50 responden berusia 22-25 tahun, dengan hasil yang didapatkan :

- $58.8 \%$ responden berdomisili di Jakarta Barat.

- $90 \%$ sangat tertarik pada konsep prasarana olahraga rekreasi.

- $32 \%$ responden pernah mencoba olahraga sejenis di kawasan Jakarta Utara; 23,5\% di kawasan Jakarta Selatan;14,7\% di kawasan Jakarta Timur; 14,7\% di kawasan Jakarta Pusat; dan terakhir dengan presentase terendah 5,9\% di kawasan Jakarta Barat.

c. Studi Preseden

Data yang menunjang dalam pendekatan desain bangunan.

d. Kajian Pustaka

Dengan mempelajari buku-buku, situs internet yang berkaitan dengan teori, standarstandar yang mengacu pada proses penyusunan program.

Pada bagian Metode, penulis perlu menjabarkan data yang akan dikumpulkan selama proses penelitian/ desain dan selanjutnya secara rinci dan runut menjelaskan metode pengumpulan data, tahapan penelitian/ desain, metode analisis dan sintesis data hingga menghasilkan pernyataan kesimpulan. Jika penulis menggunakan alat penelitian atau simulasi desain yang spesifik, maka perlu dicantumkan juga dalam bagian ini. Apabila metode yang digunakan berasal dari beberapa sumber, maka penulis perlu menjelaskan kajian terkait metode tersebut secara jelas dengan menyertakan sumber asli. Penulis 
diharapkan memaparkan secara detail alasan dalam menggunakan suatu metode tertentu.

\section{KAJIAN LITERATUR}

\section{Pariwisata di Perkotaan}

Menurut yang dikemukakan oleh Kodhyat (1983:4) Definisi pariwisata adalah perjalanan dari satu tempat ke tempat yang lain, bersifat sementara, dilakukan perorangan maupun kelompok, sebagai usaha mencari keseimbangan atau keserasian dan kebahagiaan dengan lingkungan hidup dalam dimensi sosial, budaya, alam dan ilmu. Kota merupakan destinasi dengan multimotivasi, tidak seperti resor-resor pada umumnya (Law, 1996: 3). Orang-orang datang ke suatu kota untuk berbagai tujuan: bisnis, kegiatan hiburan dan rekreasi, mengunjungi keluarga dan kerabat, atau urusan pribadi lainnya. Seringkali, mereka mengunjungi kota untuk lebih dari satu alasan. Orang yang pergi ke suatu kota untuk berbisnis, menyempatkan diri untuk mengunjungi museum atau galeri seni di kota yang dikunjunginya. Atau mereka yang dari luar negeri (wisatawan mancanegara) mengunjungi dan berwisata di kota tertentu sebagai pintu gerbang untuk mengunjungi daerah lain di sekitarnya.

Pariwisata perkotaan memiliki karakteristik lain yang khas, berbeda dengan pariwisata pada umumnya yang daya tarik wisatawanya memang ditujukan hanya untuk mereka yang berwisata. Wisatawan perkotaan menggunakan fasilitas perkotaan yang juga digunakan oleh penduduk kota sebagai daya tarik wisatanya (Law, 1996: 4).

Mengacu pada definisi-definisi yang telah dikemukakan di atas, secara lebih luas pariwisata perkotaan dapat didefinisikan sebagai: bentuk umum dari pariwisata yang memanfaatkan unsur-unsur perkotaan (bukan pertanian) dan segala hal yang terkait dengan aspek kehidupan kota (pusat pelayanan dan kegiatan ekonomi) sebagai daya tarik wisata.

Pariwisata perkotaan tidak selalu harus berada di wilayah kota atau pusat kota. Pariwisata perkotaan dapat berkembang di wilayah pesisir, misalnya, dengan mengembangkan hal-hal yang terkait perkotaan sebagai daya tarik wisatanya.

Berbeda dengan kota wisata. Kota wisata adalah kota yang memang dibangun untuk pariwisata dan wisatawan, mengandalkan pariwisata sebagai sektor utama penggerak perekonomian kota.

\section{Olahraga Rekreasi}

Olahraga merupakan bentuk kegiatan jasmani yang terdapat dalam permainan, perlombaan, dan kegiatan jasmani yang instensif dalam rangka memperoleh rekreasi, kemenangan, dan prestasi optimal (Menpora, 1984).

Rekreasi, dari bahasa Latin, re-creare, yang secara harfiah berarti 'membuat ulang', adalah kegiatan yang dilakukan untuk penyegaran kembali jasmani dan rohani seseorang. Kegiatan rekreasi biasanya dilakukan diwaktu senggang (leasuretime). Hal ini adalah sebuah aktivitas yang dilakukan seseorang selain pekerjaan. Leasure berasal dari kata "licere" (latin) yang berarti diperkenankan menikmati saat-saat yang bebas dari kegiatan rutin untuk memulihkan atau menyegarkan kembali. Kegiatan yang umum dilakukan untuk rekreasi adalah pariwisata, olahraga, permainan, dan hobi.

Dalam Undang-Undang Republik Indonesia No 3 Tahun 2005 tentang Sistem Keolahragaan Nasional juga disebutkan bahwa olahraga rekreasi adalah olahraga yang dilakukan oleh masyarakat dengan kegemaran dan kemampuan yang tumbuh dan berkembang sesuai dengan kondisi dan nilai budaya masyarakat setempat untuk kesehatan, kebugaran dan kesenangan (pasal 1 ayat 12). Dalam hal ini olahraga dan pariwisata mempunyai tujuan yang sama. Kalau olahraga bertujuan untuk memberikan kesenangan maka pariwisata adalah suatu kegiatan yang dilakukan untuk mendapatkan kesenangan.

Pariwisata untuk olahraga (Sport tourism) menurut Spillane (1987:30) dapat dibagi dalam dua kategori yaitu: 
- Big sport events yaitu peristiwa-peristiwa olahraga besar seperti Olympic games, kejuaraan ski dunia, kejuaran tinju dunia dan olahraga lainnya yang menarik perhatian tidak hanya pada olahragawannya sendiri tetapi juga ribuan penonton atau penggemarnya.

- Sporting tourism of the practicioners yaitu pariwisata olahraga bagi mereka yang ingin berlatih dan mempraktekkan sendiri seperti pendakian gunung, olahraga naik kuda, berburu, memancing dan lain sebagainya.

\section{Bowling}

Bowling adalah jenis olahraga atau permainan yang dimainkan dengan menggelindingkan bola khusus menggunakan satu tangan. Bola boling akan digelindingkan ke pin yang berjumlah sepuluh buah yang telah disusun menjadi bentuk segitiga jika dilihat dari atas.

Permainan bowling ada dua macam, yaitu pin bowling dan target bowling. Sesuai namanya, pin bowling adalah jenis permainan yang menggunakan pin.

- Pin bowling ini dibagi lagi menjadi lima jenis permainan tergantung pinnya, yaitu sepuluh pin bowling, Sembilan pin bowling, lima pin bowling, candlepin, dan duckpin. Di antara pin bowling tersebut, sepuluh pin bowling menjadi yang paling dikenal.

- Target bowling adalah jenis permainan bowling yang tidak menggunakan pin, tapi menggunakan target tertentu, misalnya mengarahkan bola ke sebuah lubang. Jenis permainan ini ada bermacam-macam, contohnya adalah carpet bowls dan irish road bowling.

\section{Sepatu Roda}

Olahraga sepatu roda berasal dari negeri Belanda, diciptakan sekitar abad ke 17 oleh seorang penggemar ice skating. Dia ingin mengubah permainan ice skating menjadi permainan yang dapat bergerak di atas tanah atau jalan keras. Tahun 1763 Joseph Marlin seorang teknisi Belgia dan pembuat alat-alat musik mencoba berlari dengan peralatan ice skating yang dilengkapi dengan roda kecil dari besi, tapi tidak bisa berkembang pada waktu itu karena ada larangan pemerintah Belanda bermain sepatu roda di jalan raya. Tahun 1863 seorang bernama James Leonard Plimton's pencipta "rocking Skate yang kemudian ia patenkan menjadi sangat popular, la kemudian dijuluki "Bapak Pencipta Sepatu Roda".

Olahraga itu kemudian populer di Amerika, Inggris dan Austria. Tahun 1876 terbentuk organisasi sepatu roda di Inggris yang bernama NSA (The National Skating Association). Tahun 1924 berdiri organisasi sepatu roda Internasional dengan nama Federasi Internationale de Roller Skating (FIRS). Sekarang sudah menyebar di lima benua dengan 42 anggota federasi nasional.

Cabang-cabang olahraga sepatu roda:

- Inline speed skating

- Aggressive inline skating

- Vert skating

- Artistic roller skating

- Freestyle slalom skating

- Inline figure skating

- Inline hockey

- Road skating

- Recreational skating 


\section{Go-Kart Indoor}

Gokart adalah varian dari kendaraan roda empat atap terbuka sederhana dan kecil untuk olahraga motor. Gokart biasanya berpacu di sirkuit skala kecil. Balapan gokar biasanya dianggap sebagai batu loncatan untuk olahraga motor yang lebih tinggi dan lebih mahal.

Olahraga ini pertama kali dikenal di Indonesia pada tahun 1967 melalui Hengky Iriawan, gagasan pembuatan mesin gokart berasal dari beberapa mahasiswa ITB (Institut Teknologi Bandung) Jurusan Mesin, ide ini diprakarasai oleh Ir. Basuki Subiyakto, M Nafi, B.Sunaryo, H Utama, dan Ir. Wibisarto. Sejak itu lapangan parkir Ganesha ITB menjadi trek gokart di Indonesia lalu dibuat trek resmi pertama yang berada di Ancol, Jakarta.

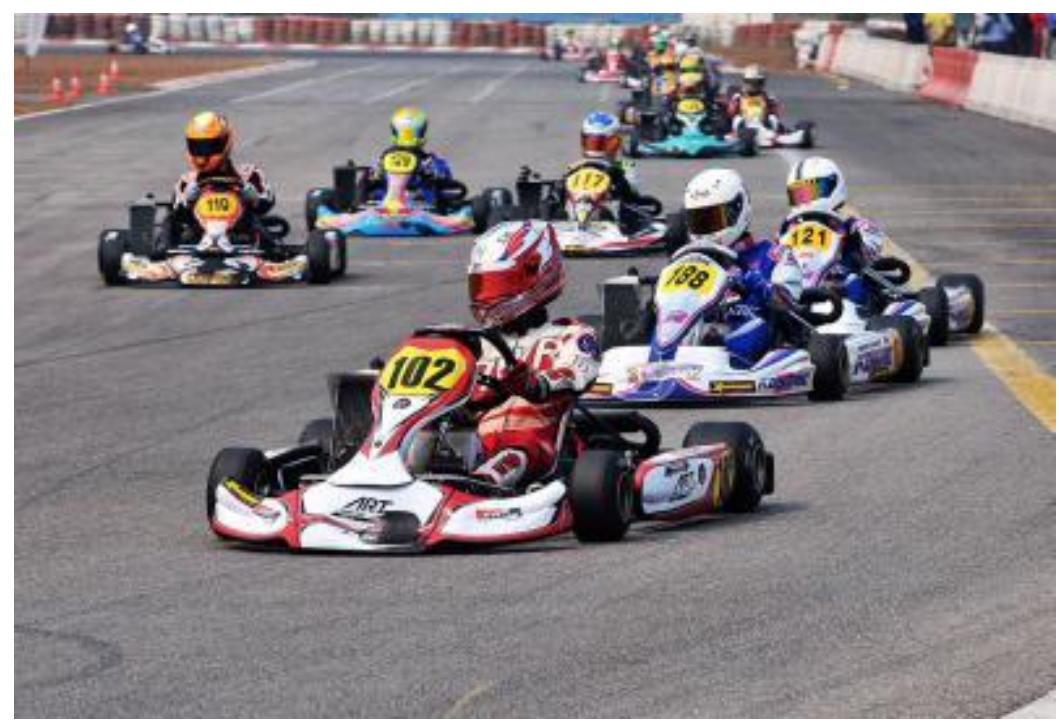

Gambar 1. Kegiatan Go-kart Outdoor

Sumber: Google.com, 2018

\section{DISKUSI DAN HASIL}

\section{Kawasan Wijayakusuma}

Kelurahan Wijayakusuma memiliki asal usul nama dari pangeran Wijaya Kusuma yang merupakan nama seorang ulama besar dari Banten yang makamnya berlokasi di Jalan Pangeran Tubagus Angke. Kelurahan ini dilalui oleh jalan Daan Mogot yang merupakan Jalan yang membentang sepanjang 27.5 KM dari Sukarasa, Tangerang, Tangerang sampai Grogol. Jalan ini merupakan bagian dari Jalan Nasional Rute 1 dan melintasi 14 kelurahan salah satunya kelurahan Wijayakusuma.

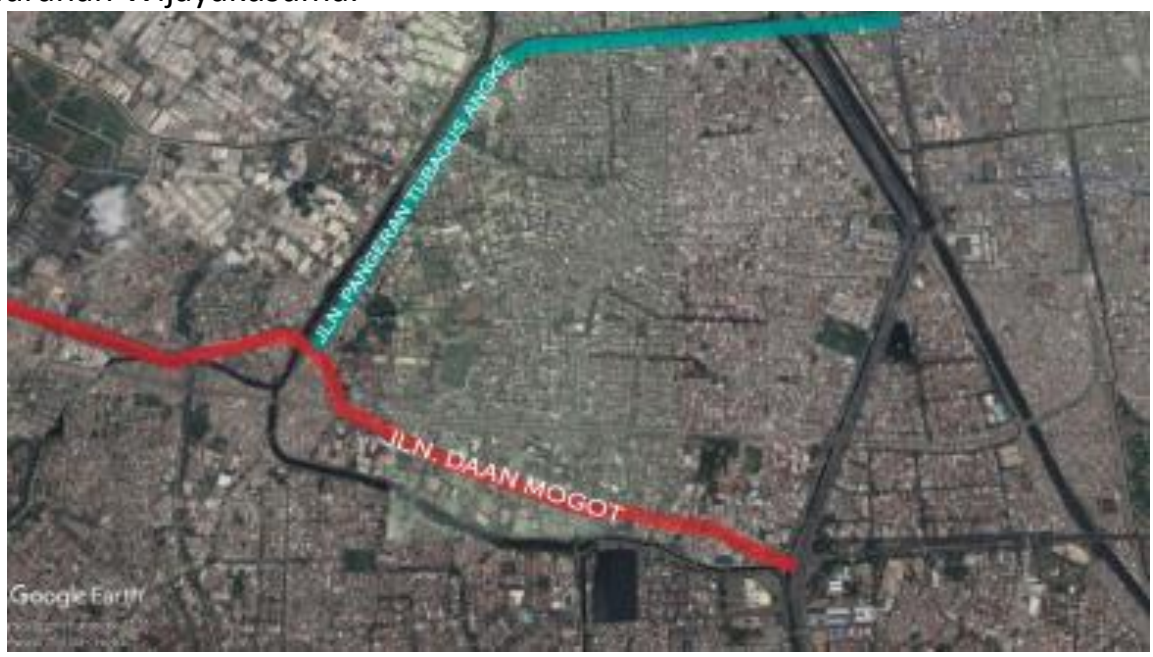

Gambar 2. Jalan besar yang melintasi kawasan Wijayakusuma.

Sumber: Googlemaps.com, 2018 
Kawasan Wijayakusuma memiliki fasilitas yang sangat memadai dengan adanya rumah sakit, apotik, pasar, area kuliner, serta fasilitas ibadah yang lengkap (terdapat gereja, masjid, dan pura). Kawasan ini juga banyak memiliki fasilitas pendidikan (SD, SMP, SMA) yang bisa menjadi target user proyek. Jika dibandingkan zonasi fasilitas sarana dan prasarana olahraga dengan banyaknya perumahan di kawasan ini tidak seimbang dan hanya sedikit fasilitasnya.

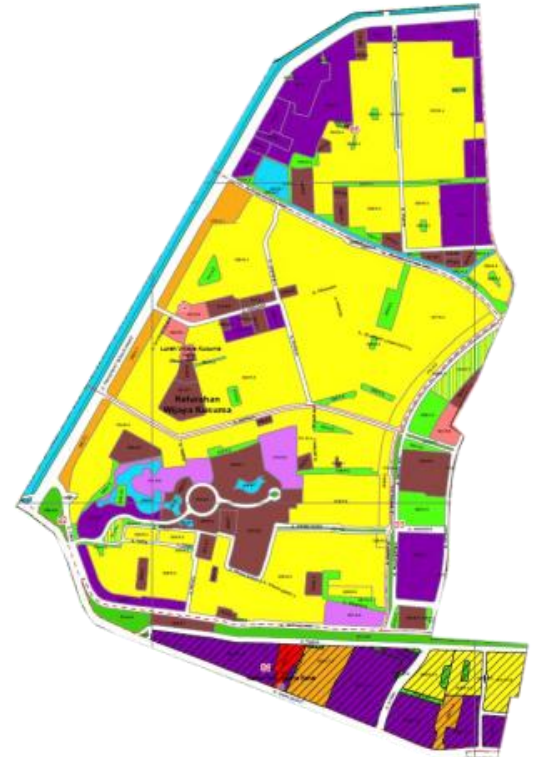

Gambar 3. RDTR kawasan Wijayakusuma

Sumber: Dinas Tata Kota, 2018

Untuk fasilitas olahraga sejenis, kawasan Wijayakusuma tidak memiliki fasilitas olahraga yang sama dengan proyek yang dibuat. Maka itu diharapkan proyek ini bisa menjadi gagasan baru dan berbeda sehingga bisa unggul dan tidak memiliki pesaing sejenis
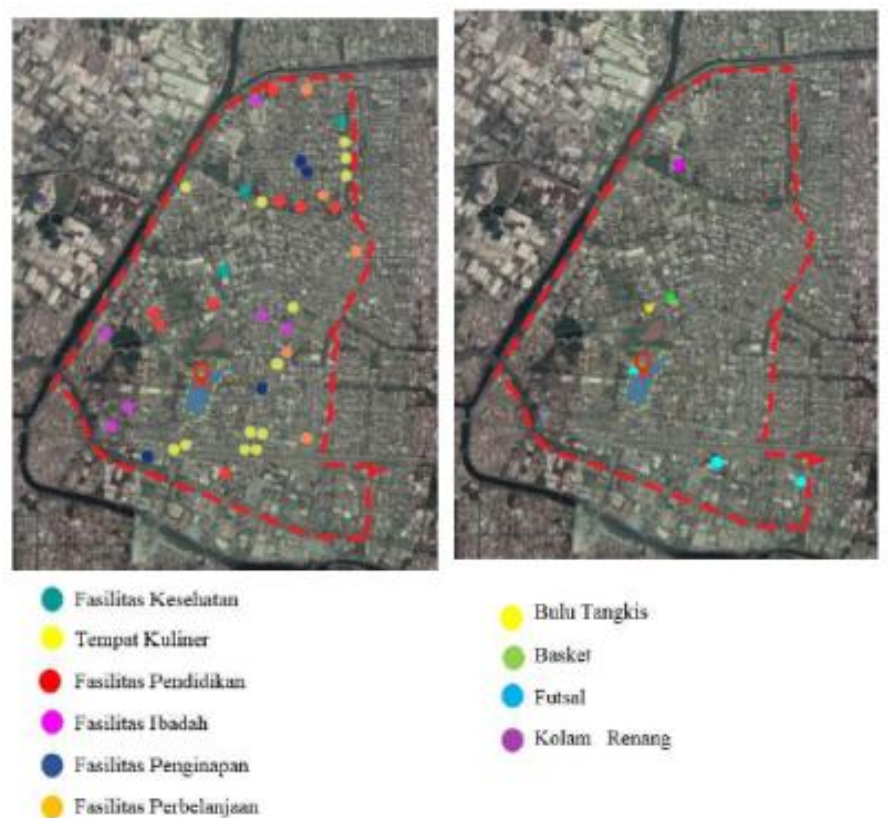

Gambar 4. Mapping Fasilitas Kawasan Wijayakusuma Sumber: Googlemaps.com, 2018

Tapak yang dipilih untuk perancangan proyek ini adalah tapak di Jalan Karya Barat no. III merupakan sebuah tanah kosong dengan RDTR fasilitas sarana dan prasarana olahraga yang strategis untuk membangun proyek ini. 


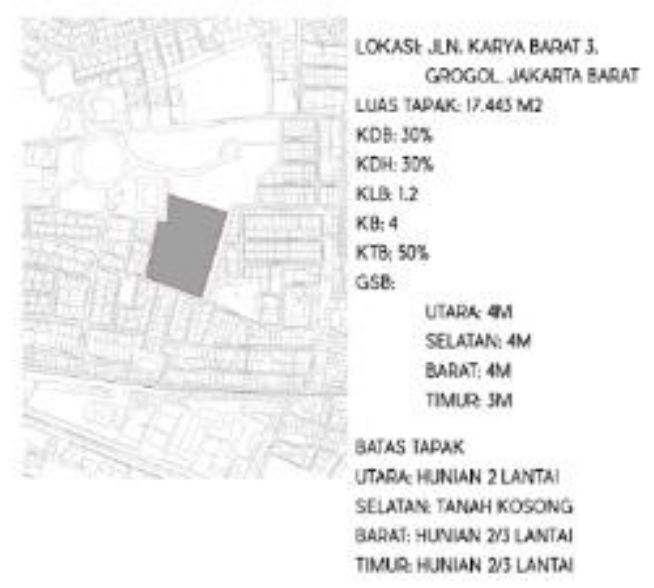

Gambar 5. Informasi tapak

Sumber: Dokumen Pribadi, 2018

\section{Konsep Perancangan}

Kondisi dan analisa tapak yang telah diolah kemudian menjadi acuan pembentukan massa bangunan yang memiliki konsep sirkulasi dan ruang terbuka untuk kawasan.

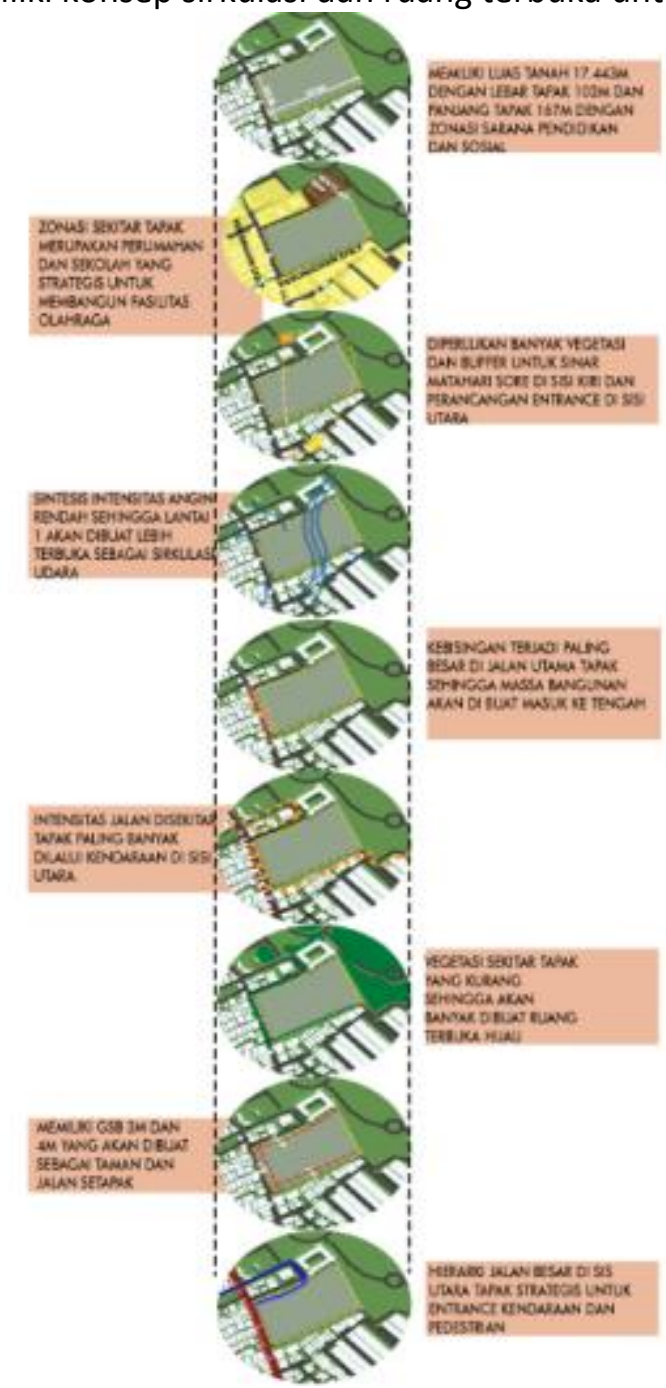

Gambar 6. Sintesis dan Analisa tapak Sumber: Dokumen Pribadi, 2018 

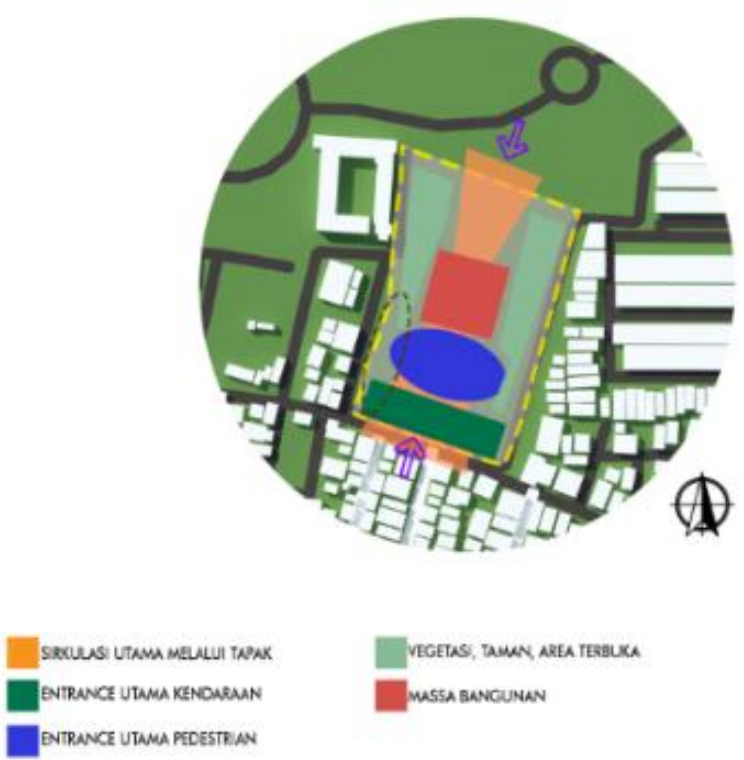

Gambar 7. Zoning Horizontal

Sumber: Dokumen Pribadi, 2018

Gambar 8. Proses pembentukan massa bangunan.

Sumber: Dokumen Pribadi, 2018

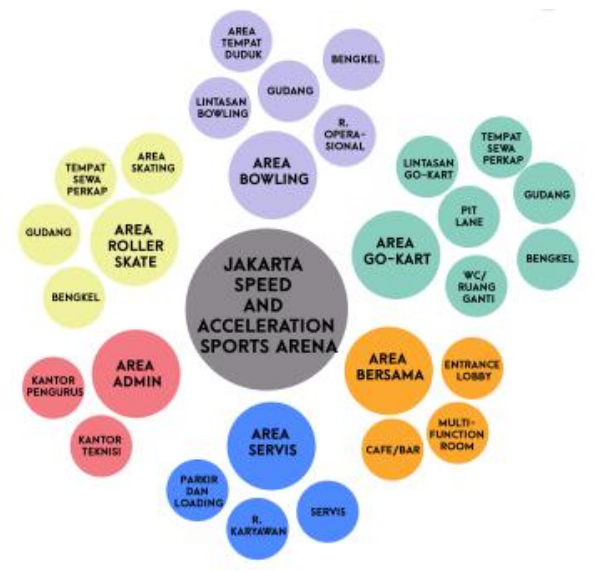

Gambar 9. Program aktivitas proyek

Sumber: Dokumen Pribadi, 2018

Massa bangunan menjadi pusat dari tapak dan menghubungkan kawasan-kawasan disekitarnya. Untuk program aktivitas yang dimuat proyek ini akan ada tiga olahraga utama sebagai program utama dan program-program penunjang lain seperti café, restaurant, retail, community club, RTH, dll.

Jakarta Speed and Acceleration Sports Arena ini memiliki luas tapak dan luas bangunan dengan ketinggian 3 lantai utama dan 1 lantai semi-basement dan dua lantai basement. Berdasarkan hasil analisi tapak dan tipologi ruang setiap cabang olahraga maka dirancang zoning vertikal dimana pembagian fungsi tiap lantai sebagai berikut:

Lantai 1 : entrance utama, retail, restoran, café, kantor administrasi, open space.

Lantai 2 : Arena roller skating.

Lantai 3 : Arena permainan bowling.

Lantai semi-basement: entrance kendaraan, entrance go-kart indoor

Lantai Basement 1 : Arena Go-kart Indoor. 
Lantai Basement 2 : Parkir kendaraan, utilitas, musholla, smoking area.

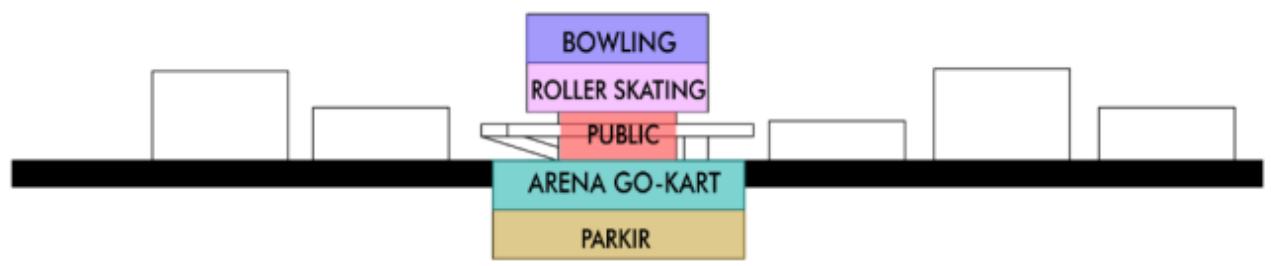

Gambar 1. Zoning bangunan secara vertikal.

Sumber: Dokumen Pribadi, 2018

Focal point dari proyek ini adalah adanya track go-kart yang mengelilingi bangunan dan memiliki second-skin berupa rangka struktur baja yang memiliki bentuk dasar persegi dengan berbagai putaran sehingga membuat bangunan semakin terlihat unik dan menarik yang juga melengkapi kriteria sebuah bangunan atraksi turis.

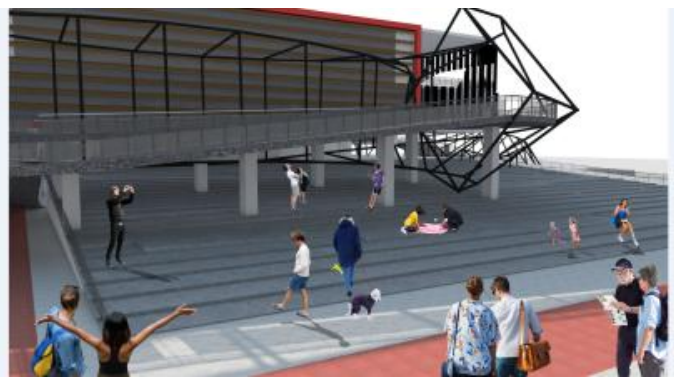

Gambar 2. Rangka track outdoor yang menjadi focal point bangunan Sumber: Dokumen Pribadi, 2018

\section{KESIMPULAN DAN SARAN}

Pariwisata di perkotaan belum banyak diterapkan di kota Jakarta yang kebanyakan berupa pusat perbelanjaan saja, bersifat monoton dan konsumerisme tinggi, untuk bisa tetap membuat masyarakat jakarta sehat dan melepas penat kegiatan sehari-hari diperlukan sebuah prasarana olahraga yang tidak hanya untuk olahraga yang bersifat prestasi tetapi juga untuk rekreasi. Dalam perancangan Jakarta Speed and Acceleration Sports Arena ini menawarkan program utama olahraga rekreasi dengan menambahkan aktivitas public space dan open space yang selalu bisa digunakan oleh masyarakat sekitar, bangunan dibagi menjadi tiga zoning vertikal dimana di setiap lantai akan memiliki satu fungsi olahraga yang memaksimalkan pengalaman suasana setiap cabang olahraga.

\section{UCAPAN TERIMA KASIH}

Terima kasih saya ucapkan kepada warga kawasan Wijayakusuma khususnya warga Jln. Karya Barat bersedia kawasan tempat tinggalnya diobservasi dan diamati sebagai tapak proyek. Serta kepada Jaya Ancol Bowling, dan Speedy Karting yang sudah bersedia dijadikan acuan dalam proses perencanaan proyek ini.

\section{REFERENSI}

Architects, C. (2010, Januari 20). Bowling Pitch. Diakses Juli 13, 2018, from Archdaily: https://www.archdaily.com/47113/bowling-pitch-chartierdalix-architects

Architects, F. a. (2017, April 22). Cycling Center. Diakses Juli 13, 2018, from Archdaily: https://www.archdaily.com/867673/cycling-center-ferdinand-and-ferdinand-architects. 13 Juli 2018.

Dwiyogo, W. (2009). Olahraga dan Pembangunan. Malang: Wineka Media.

Farrel, P. (1991). The Process of Recreation Programming Theory and Technique. Venture Pub. 
John, G., \& Heard, H. (1981). Handbook of Sports and Recreational Building Design. London: The Architectural Press.

Karting-Bowling. (2005). Retrieved Juli 13, 2018, from Arval: http://www.arvalarchi.fr/project/karting-bowling-jaux/

Specht, J. (2014). Architectural Tourism; Building for Urban Travel Destination. Germany: Springer Gabler.

SYRA_Schoyerer. (2015, Agustus 24). Speed Skating Arena Geisingen. Retrieved Juli 13, 2018, from Archdaily: https://www.archdaily.com/793846/speed-skating-arena-geisingen-syraschoyerer-architekten

Wardaya, A. P. (2018). Potensi Sport Tourism sebagai daya tarik wisata di Malang Raya. Jurnal administrasi bisnis, 2. 